\title{
Browsing evidence of the native and near-threatened Pudu puda deer in restoration plantings on Chiloé Island, Chile
}

\author{
Evidencia de ramoneo por el ciervo nativo y casi amenazado Pudu puda en plantaciones \\ de restauración en la Isla de Chiloé, Chile
}

\author{
Andreas Burger ${ }^{1}$, Jan R. Bannister ${ }^{2 *}$, Nicole Galindo ${ }^{2}$, Rodrigo Vargas-Gaete ${ }^{3}$, Osvaldo J. Vidal ${ }^{4}$ \\ \& BASTIENNE SCHLEgEL ${ }^{5}$
}

${ }^{1}$ Institute of Botany and Landscape Ecology, University of Greifswald, Soldmannstr. 15, 17487 Greifswald, Germany.

${ }^{2}$ Instituto Forestal, Oficina Chiloé, Nercón s/n, Castro, Isla de Chiloé, Chile.

${ }^{3}$ Laboratorio de Biometría, Departamento de Ciencias Forestales, Universidad de la Frontera, Av. Francisco Salazar 01145, Temuco, Chile.

${ }^{4}$ Laboratorio de Botánica, Instituto de la Patagonia, Universidad de Magallanes, Avenida Bulnes 01890, Punta Arenas, Chile. 5Instituto Forestal, Sede Los Ríos, Fundo Teja Norte, Valdivia, Chile.

*jbannister@infor.cl

\begin{abstract}
Few studies have focused on the actual extent and spatial patterns of browsing in relation to forest restoration, especially when browsing is done by deer with conservation status. Here, we present data from three forest restoration experiments located in priority forests for restoration in Chiloé Island in Chile. The aim of this study is to report evidence of browsing of the southern pudu (Pudu puda), a native and Near Threatened deer species. We visually assessed browsing for all individual seedlings and calculated the average browsing extent per plot and treatment. Since pudus as well as other deer species are known to preferably feed in open spaces, we hypothesized that Pilgerodendron uviferum planted seedlings will present higher browsing rates in places with lower shrub cover (bogs) and canopy cover (upland areas) (H1). In the case of degraded North-Patagonian forests we hypothesized that Nothofagus nitida planted seedlings will present higher browsing rates in places with higher \%PPFD (Photosynthetic Photon Flux Density) and/or lower residual basal area (H2). Our results indicate that browsing ranged from $9.3 \%$ up to $84.0 \%$ depending on tree species and site condition. In burned forests, browsing was significantly higher $(\mathrm{p}<0.01)$ when shrubs were removed $(84.0 \% \pm 9.9)$ than by retaining them $(68.9 \% \pm 11.6)$. In degraded old-growth forests, we found significantly higher browsing in places with higher degradation $(\mathrm{p}<0.05)$. Furthermore, \%PPFD was significantly correlated with browsing (rho: $0.535 ; \mathrm{p}<0.01$ ). Based on our results, forest restoration efforts in Chiloé Island will face a great challenge in balancing the protection of Near Threatened wildlife and the restoration of tree species with conservation problems, especially in open/disturbed areas, where higher browsing was found.
\end{abstract}

KEYWORDS: Chile, forest management, forest restoration, herbivory, southern pudu.

\section{RESUMEN}

Escasos estudios han relacionado el ramoneo nativo, sus patrones espaciales y su relación con la restauración de bosques, especialmente cuando el ramoneo es realizado por especies en categorías de conservación. En este estudio presentamos evidencia de ramoneo de pudú (Pudu puda) en tres experimentos de restauración de bosques ubicados en bosques prioritarios para la restauración en la Isla de Chiloé, Chile. La presencia de ramoneo fue visualmente evaluada en todas las plantas establecidas en los experimentos y se calculó la tasa media de ramoneo por unidad experimental y tratamiento. Los pudúes son conocidos por preferir espacios abiertos, por lo que se plantean las siguientes hipótesis: En bosques quemados de Pilgerodendron uviferum, las plántulas establecidas presentarán tasas de ramoneo más altas en lugares con una cubierta de arbustos y árboles más baja (H1); y en bosques adultos siempreverdes degradados las plántulas establecidas presentarán mayores tasas de ramoneo en lugares con mayor iluminación y menor área basal residual (H2). Nuestros resultados indican que el ramoneo varió entre 9,3 y 84,0\% según las especies arbóreas y las condiciones del sitio. En bosques quemados, el ramoneo fue significativamente mayor $(\mathrm{p}<0,01)$ al eliminar arbustos $(84,0 \% \pm 9,9)$ que al retenerlos $(68,9 \% \pm 11,6)$. En bosques adultos degradados, encontramos ramoneo significativamente mayor en lugares con mayor degradación $(\mathrm{p}<0,05)$. Además, la iluminación se correlacionó significativamente con el ramoneo (rho: 0,$535 ; \mathrm{p}<0,01$ ). En este contexto, los esfuerzos de restauración en Chiloé enfrentarán en los próximos años un gran desafío que es equilibrar la protección de especies emblemáticas como el pudú, con la restauración de especies arbóreas con problemas de conservación.

Palabras clave: Chile, herbivoría, manejo forestal, pudú, restauración de bosques. 


\section{INTRODUCTION}

In the last 50 years, the global interest about the impact of deer on forests has increased rapidly, especially in relation to the effect of browsing on biodiversity (Côté et al. 2004). Generally, browsing is defined as feeding on woody plants in contrast to grazing, which is referred to grasses and forbs (Chapman \& Reiss 1999). Worldwide, the focus of research about the extent of browsing has primarily been on temperate and boreal forests of North America (Gill 1992, Côté et al. 2004) and Europe (Gerhardt et al. 2013). In both continents, negative effects of browsing on restoration plantings and regeneration of seedlings have been identified (Motta 1996, Partl et al. 2002). In the southern hemisphere, some studies have been set in the temperate forests of Chile and Argentina, where domestic (Echevarría et al. 2014), native (Rebertus et al. 1997, Martínez Pastur et al. 1999, Cavieres \& Fajardo 2005, Promis et al. 2010, Puig et al. 2014), and different types of browsers (Grosse 2001, Collado et al. 2008) were considered. However, most of the research on browsing in these forests has been done focusing on introduced-wild species (e.g. Lepus europaeus Pallas 1778) or the native Lama guanicoe Müller 1776. To the best of our knowledge, there is no comprehensive study about browsing by Pudu puda (Molina, 1782), a native deer of the Patagonian temperate forests (Fig. 1).

Pudu puda, the southern pudu, is known as the smallest deer in the world with $<15 \mathrm{~kg}$ weight and $30-40 \mathrm{~cm}$ height (Bubenik et al. 2000, Jiménez 2010). Pudus are considered as Near Threatened (NT) by the IUCN as well as listed on CITES-Appendix I (Silva-Rodríguez et al. 2016). Their distribution for Chile is described between $35^{\circ} 10^{\prime} \mathrm{S}$ and $46^{\circ} 45^{\prime}$ S (Glade 1985), which is partly located in one of the world's 25 biodiversity hotspots (Myers et al. 2000). According to some estimations, the total population of this species in Chile and Argentina does not exceed 10,000 individuals (Jiménez 2010). It is well known that habitat fragmentation and loss (by deforestation) as well as other anthropogenic effects, like pressure of domestic animals, constantly threaten pudus (Jiménez 2010). For instance, feral and domestic dogs were reported to have high direct and indirect impact on pudus (Silva-Rodríguez \& Sieving 2012), whereas wild predation is expected to have only very little direct impact on them (Jiménez et al. 1990). Nevertheless, previous studies considered pudus as abundant in Chiloé Island, North Patagonia (Glade 1985, Jiménez 1995). This perception is also supported by frequent sightings of forest managers (Tantauco Park, personal communication).

For North America (Côté et al. 2004, White 2012) and other parts of the world (Echevarría et al. 2014, Clasen et al. 2015, Sweetapple et al. 2016), browsing behavior and effects of browsing on tree species (e.g. changes in shape or decelerated growth) have been studied fairly well. While studies of browsing by pudus in Chile exist (Wetterberg 1972, Neumann 1992), there is still a great deficit in research on the actual extent and patterns (e.g. preferential habitats and species) of browsing in relation to forest restoration. Due to forest fragmentation, degradation and heavy deforestation, restoration of native temperate forests constitutes a major challenge in Chile, especially in Chiloé Island, were currently several restoration experiments exist (Bannister et al. 2016). In this island, evergreen North-Patagonian forests and Pilgerodendron uviferum (D. Don) Florin dominated bog forests are priority forests for conservation and restoration (Bannister et al. 2014, Bannister \& Donoso 2013). While higher browsing in open
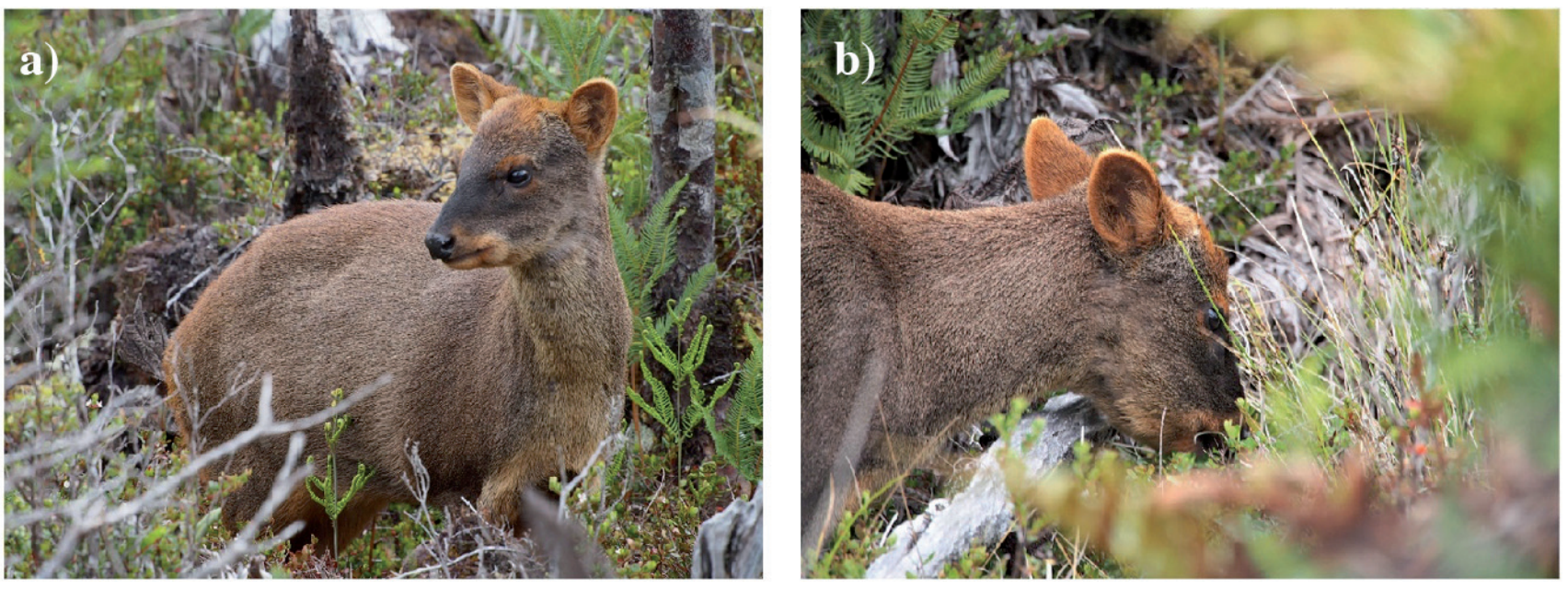

Figure 1: Pudu puda in burned Pilgerodendron uviferum forests of Lago Chaiguata, Chiloé Island (a) and Browsing of Pudu puda inside a restoration planting (b). / Pudu puda en bosques quemados de Pilgerodendron uviferum en el Lago Chaiguata, Isla de Chiloé (a) y ramoneo de Pudu puda dentro de una plantación de restauración (b). 
spaces has been determined for many ungulates (Cavieres \& Fajardo 2005, Casabon \& Pothier 2007, Kuijper et al. 2009), this pattern has equally been found for pudus in restoration plantings (Bannister et al. 2013). Similar to other deer species, Jiménez (1995) noticed a preference of pudus to open sites, where vegetation is rich and abundant. Accordingly, restoration plantings in open spaces may constitute a convenient feeding habitat for pudus. Therefore, we expect to find interference between browsing and restoration plantings. This interference should be evident in pioneer species commonly planted in restoration plantings like the broadleaved species Nothofagus nitida (Phil.) Krasser, which has been determined as a favorable tree species (Jiménez 2010), in degraded evergreen NorthPatagonian forests or in the conifer P. uviferum in burned forests, especially in more degraded spaces or places with lower secondary shrubland cover (Bannister et al. 2013). These degraded or open spaces, which are characterized by reduced understory and/or overstory, can be identified by both basal area and \%PPFD (Lusk \& Ortega 2003, Bannister et al. 2013). Consequently, low basal area or high \%PPFD indicate degraded forest conditions.

Here, we present data from three separate experiments. Two are located in burned forests previously dominated by P. uviferum and are currently dominated by dense secondary shrublands in bog areas or some secondary forests in upland areas. The third one is situated in degraded North-Patagonian forests previously dominated by $N$. nitida and other tree species and currently dominated by dense thickets of Chusquea sp. and some residual trees. In burned forests, we hypothesized that $P$. uviferum planted seedlings will present higher browsing rates in places with lower shrub cover (bogs) and canopy cover (upland areas) (H1). In the case of degraded North-Patagonian forests we hypothesized that $N$. nitida planted seedlings will present higher browsing rates in places with higher \%PPFD (Photosynthetic Photon Flux Density) and/or lower residual basal area (H2). Based on our results, we analyzed the implications of browsing by pudus on forest restoration, and discuss the challenging problem of balancing wildlife protection and forest restoration in these forests. This work is the first one intensively studying the extent and some patterns of browsing by pudus in restoration plantings of Chile and Argentina.

\section{METHODS}

STUDY AREA AND RESTORATION EXPERIMENTS

The study was located between $42^{\circ} 43^{\prime}$ and $43^{\circ} 07^{\prime} \mathrm{S}$ on Chiloé Island, North Patagonia, Chile, between the northern and southern temperate bioregions of Chile (Bannister et al. 2012). We collected information from three different restoration experiments on Chiloé Island: Parque Tantauco 1 and Parque Tantauco 2, located in burned forests previously dominated by $P$. uviferum and Huillinco, located in degraded evergreen North-Patagonian forests (Fig. 2). The climate in the study area is oceanic with mild temperatures (mean annual $10^{\circ} \mathrm{C}$ ) and high annual precipitations, exceeding $2500 \mathrm{~mm}$ up to $6000 \mathrm{~mm}$ (Di Castri \& Hajek 1976). Additionally, all restoration experiments share the background of degradation by anthropogenic forest fires or selective cutting. Accordingly, a heterogeneous character of secondary forests and shrubland is prevailing.

In Parque Tantauco, an isolated conservation area in southern Chiloé Island $\left(43^{\circ} \mathrm{S}\right)$, two restoration experiments with $P$. uviferum were established. Parque Tantauco 1 and 2. The physiography of this conservation area has been shaped by the last glaciation, which created a mix of hills from glacial till and shallow valleys, with extremely acidic, poorly drained soils with Gley horizons (Villágran 1988). The altitude in this area ranges between 50 and $280 \mathrm{~m}$ above sea level. Both restoration sites were burned in 1942; hence, shrubs, dead trunks, and some secondary forests are prevalent in the landscape. The difference between both experiments is that Parque Tantauco 1 was established in a burned bog that currently is covered by dense secondary shrublands of Bacharis sp. and Gleichenia sp. In contrast, Parque Tantauco 2 was established in upland areas with better drainage and therefore is currently covered by secondary forests dominated by Drimys winteri J.R. Forst. \& G. Forst. or Tepualia stipularis (Hook. \& Arn.) Griseb. Huillinco $\left(42^{\circ} \mathrm{S}\right)$ is also shaped by the last glaciation with a hilly physiographic character but with better soil conditions (e.g. better drainage and richer in nutrients). Therefore, an uneven-aged and structurally diverse forest has been developed in the last millennials in this area (Bannister \& Donoso 2013). However, during the 80s and 90s intense selective cutting was applied to these forests which drastically opened the continuous canopy cover with a resultant proliferation of dense thickets of Chusquea sp. in the understory. Today, these forests are dominated by Chusquea sp. in the understory and some big remnant trees in the overstory.

RESEARCH DESIGN AND MEASUREMENT

The three restoration experiments used in this study were not designed specifically for measuring browsing, however they represent ideal places to study browsing patterns since they were established as long-term research experiments. Parque Tantauco 1 was established in 2014 and consists in 30 cluster plantings, each of them of 41 seedlings of $P$. uviferum (total 1230 seedlings) in a matrix of burned bog forests previously dominated by this conifer. In this experiment two treatments were applied. First, in half of the clusters (15 experimental units), a complete shrub-removal inside the radius of the cluster was applied in order to remove the secondary shrubs of Bacharis sp. and Gleichenia sp. In the other 15 clusters, the shrubs were retained and only were removed 
inside a radius of $50 \mathrm{~cm}$ from each seedling of $P$. uviferum, creating a "cup" or "hole" in the shrub cover to avoid direct competition. The original idea behind this experiment was to study if secondary shrubs facilitate the growth of planted P. uviferum seedlings in these burned ecosystems. In total, we measured browsing for Parque Tantauco 1 three times: three months after establishment in 2014, 2015, and 2016.

Parque Tantauco 2 was established in 2009 and consists of three P. uviferum plantings of $120 \mathrm{~m}^{2}$ in a matrix of upland burned sites with secondary forests (Bannister et al. 2013). In this experiment, three treatments representing different canopy/light environments were assigned: (a) UFGap: small open areas with a mean photosynthetic photon flux density (\%PPFD) of $78.2 \%$; (b) UF-50: semi-open areas, where $50 \%$ of canopy trees were thinned (mean: $37.6 \%$ PPFD); and (c) UF-Den: $100 \%$ canopy cover (mean: $10.9 \%$ PPFD). \%PPFD was measured with a LICOR 1400 Data logger and LI250 point quantum sensors right above the apical shoot of the seedlings. The first results of this experiment were included in Bannister et al. (2013). These three treatments were assigned to each planting. Twelve seedlings of $P$. uviferum were planted every $2 \times 2 \mathrm{~m}$ in each unit with a $3 \mathrm{~m}$ buffer zone around the perimeter, with 36 plants per each treatment and 108 seedlings in total. After planting, we measured browsing in 2010, 2011, and 2014.

Huillinco was established in 2014 and consist in 45 experimental units of $400 \mathrm{~m}^{2}$ each on a total area of 4.5 ha. In each experimental unit, the complete Chusquea quila Kunth understory was removed and $500 \mathrm{~m}^{2}$ were retained as buffer zone. Additionally, in each experimental unit, one half $\left(200 \mathrm{~m}^{2}\right)$ was left for natural regeneration and in the other half $\left(200 \mathrm{~m}^{2}\right)$, a cluster planting of $50(2 \times 2 \mathrm{~m})$ Nothofagus nitida seedlings of $40 \mathrm{~cm}$ height was established. The original idea behind the establishment of this experiment was to see which was a better option after removal of the Chusquea sp. understory, if natural regeneration or N. nitida plantings. For the purpose of this study, only the active restoration treatment was considered since browsing was only measured there. After planting, we measured browsing in 2015 and 2016. Besides browsing, we also measured \%PPFD (like in Parque Tantauco 2) and the residual basal area (rBA) in each experimental unit. Subsequently, three forest conditions were defined through rBA as "disturbed forest" (mean: $24.92 \mathrm{~m}^{2} \mathrm{ha}^{-1} ; 19$ units, strong forestry use), "semi-disturbed forest" (mean: $51.95 \mathrm{~m}^{2} \mathrm{ha}^{-1}$; 14 units, intermediate forestry use) and "undisturbed forest" (mean: $72.10 \mathrm{~m}^{2} /$ ha; 12 units, no apparent forestry use).

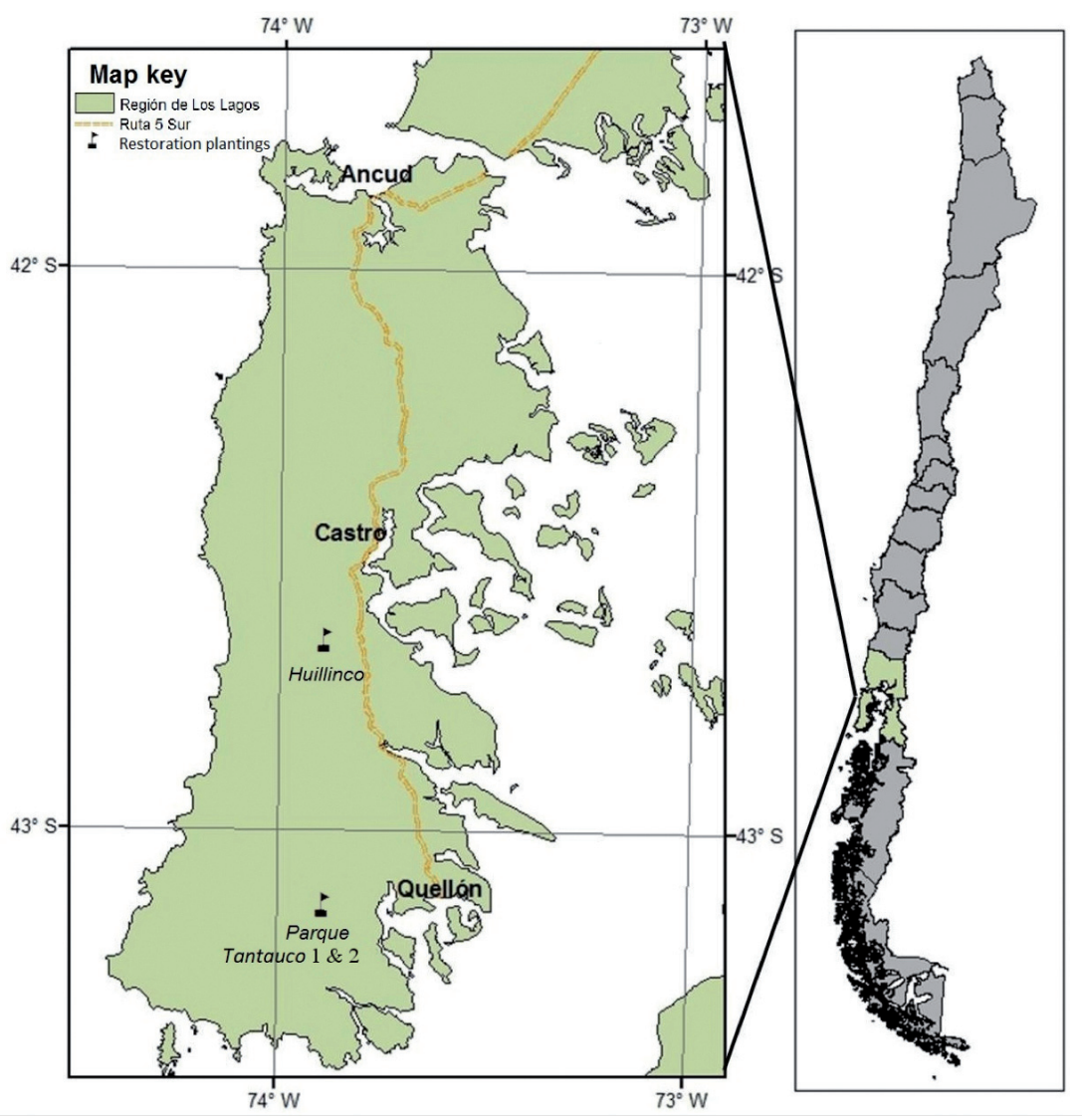

Figure 2: Study area on Chiloé Island, North Patagonia, Chile. The three restoration experiments are indicated with flags; two sites are in Parque Tantauco. / Área de estudio en la Isla Grande de Chiloé, Patagonia Norte, Chile. Los tres experimentos de restauración están indicados con banderas; dos sitios están en Parque Tantauco. 
We calculated the browsing rate by calculating the percentage of all browsed plant individuals of one plot. Subsequently, we proceeded with all plots of each treatment in equal measure. In the whole manuscript, browsing rate is used synonymous to browsed/plot. Browsing by pudus was visually assessed and classified as "browsed" or "nonbrowsed" in every single experimental unit and all individual plants. Living plants were determined as "browsed" if some part of it showed clear signs of feeding, i.e. either solely broken apical shoots and/or missing lateral branches, or together with bitten leaves (Bannister et al. 2013). For emphasizing the presence/absence of browsing in our study, we did not record the intensity and location of browsing per plant and treated one branch browsed to many branches browsed equally. We applied the same method for all three restoration plantings and data collections.

In order to avoid browsing by other animals (e.g. cattle, sheep, etc.), fences were implemented in Huillinco. Nevertheless, browsing by pudus cannot be prevented by those fences due to pudu's short height and the big mesh size of the fences as well as occasionally given trenches below the fences (Fig. 1). However, fences might still constitute an obstacle and therefore reduce browsing to some degree. In the case of the restoration plantings in Parque Tantauco 1 and 2 , fences were not necessary since interference by domestic animals can be ruled out owing to the isolation of this conservation area.

DATA ANALYSIS

All data analyses were preceded by testing for normality and homogeneity of variances with Shapiro-Wilk (for $\mathrm{n}<50$ ) and Levene's test with the 'car' package in R (Fox \& Weisberg 2011; R Core Team 2016). In case of heteroscedasticity or non-normal distribution in datasets (browsed/plot, \%PPFD, residual basal area), the Mann-Whitney U-test (2 groups) and Kruskal-Wallis test ( $>2$ groups) were applied to test for significant differences between groups. In case of significant differences, the Kruskal-Wallis-post-hoc test after Nemenyi of the 'PMCMR' package was performed to identify the significant group/s in a multiple comparison (Pohlert 2014). In order to test for correlation between browsed/plot and $\%$ PPFD or residual basal area, respectively, Spearman's correlation test was applied. Throughout the analyses, differences between values were considered significant at $p$ $<0.05$. Since the cause of seedling death could not clearly be attributed to browsing; only living plants were included in the analyses and data processing. In addition, browsed seedlings retained their "browsing-status" in the statistical analysis throughout the years if being browsed once. All work on data analyses and graphs were performed with $R$ and SigmaPlot (R Core Team 2016, SigmaPlot 2016).

\section{RESULTS}

In all three restoration experiments, browsing by pudus could be identified for P. uviferum and Nothofagus nitida seedlings (Table 1 and Fig. 3). The overall browsing rates per plot ranged from $9.3 \%$ (Nothofagus nitida) up to $84.0 \%$ (Pilgerodendron uviferum). On sites measured two or more times, an increase in browsing per year of min. $2.78 \%$ (2010-2011) and max. 33.61\% (2014-2015) was noticed (Fig. 3). Altogether, our results indicate that more than a third of planted seedlings (35.9\%) have been browsed.

In Parque Tantauco 1, we identified high browsing rates of $P$. uviferum seedlings for both treatments "shrubremoval" $(57.67 \% \pm 17.94)$ and "shrub-retention" $(50.22 \%$ \pm 12.96 ) in 2015. In 2016, browsing rates increased for

TABLE 1: Browsing evidence in restoration experiments located in Chiloé Island, North Patagonia, Chile. In "browsed/plot", the last measurement is stated. Browsing period corresponds to the total time of browsing interference since the establishment of the restoration plantings (brackets). / Evidencia de ramoneo en experimentos de restauración ubicados en la Isla de Chiloé, Patagonia Norte, Chile. En "browsed / plot" se indica la última medición. El período de ramoneo corresponde al tiempo total de ramoneo desde el establecimiento de las plantaciones de restauración (paréntesis).

\begin{tabular}{|c|c|c|c|c|c|}
\hline Site & SPeCIES & TREATMENT-CONDITION & MEASUREMENTS & $\begin{array}{l}\text { BROWSED/PLOT } \pm \text { SD } \\
(\%)\end{array}$ & BROWSING PERIOD \\
\hline \multirow{3}{*}{ Huillinco } & \multirow{3}{*}{ Nothofagus nitida } & Disturbed forest & 2015 & $32.2 \pm 24.5$ & \multirow{3}{*}{2 years $(2014)$} \\
\hline & & Semi-disturbed forest & $\&$ & $14.9 \pm 14.8$ & \\
\hline & & Undisturbed forest & 2016 & $9.3 \pm 6.5$ & \\
\hline \multirow{2}{*}{ Parque Tantauco 1} & \multirow{2}{*}{$\begin{array}{l}\text { Pilgerodendron } \\
\text { uviferum }\end{array}$} & Shrub-retention & 2014 & $68.9 \pm 11.6$ & \multirow{2}{*}{2 years (2014) } \\
\hline & & Shrub-removal & $2015 \& 2016$ & $84.0 \pm 9.9$ & \\
\hline \multirow{3}{*}{ Parque Tantauco 2} & \multirow{3}{*}{$\begin{array}{l}\text { Pilgerodendron } \\
\text { uviferum }\end{array}$} & Gaps & \multirow{3}{*}{$\begin{array}{c}2010 \\
2015 \& 2016\end{array}$} & $38.9 \pm 53.6$ & \multirow{3}{*}{5 years $(2009)$} \\
\hline & & Semi-Dense & & $19.4 \pm 26.8$ & \\
\hline & & Dense & & $19.4 \pm 33.7$ & \\
\hline
\end{tabular}


"shrub-removal" to $84.0 \%( \pm 9.9)$ and for "shrub-retention" to $68.9 \%( \pm 11.6)$. For the measurement in 2016 , we found significantly higher $(\mathrm{p}<0.01)$ browsing in the treatment "shrub-removal" than "shrub-retention" (Fig. 3). Parque Tantauco 2 similarly presented browsing rates in all three different treatments of light conditions ranging from $19.4 \%$ to $38.9 \%$ in the last measurement (2014). There were no significant differences for browsing rates between "gaps", "semi-dense", and "dense" conditions (Fig. 3).
In Huillinco, browsing increased along a disturbance gradient from $9.3 \%( \pm 6.5)$ in the "undisturbed forest" to $14.9 \%( \pm 14.8)$ in the "semi-disturbed forest" to $32.2 \%$ $( \pm 24.5)$ in the "disturbed forest". We found significantly higher browsing of $N$. nitida seedlings $(\mathrm{p}<0.05)$ in "disturbed" than "undisturbed" forests in the second measurement of 2016 (Fig. 3). Additionally, there was a significant positive correlation between \%PPFD and browsing (rho: $0.535 ; \mathrm{p}<0.01$ ). In the case of residual basal area the correlation was not significant ( $p>0.05)$ (Fig. 4).
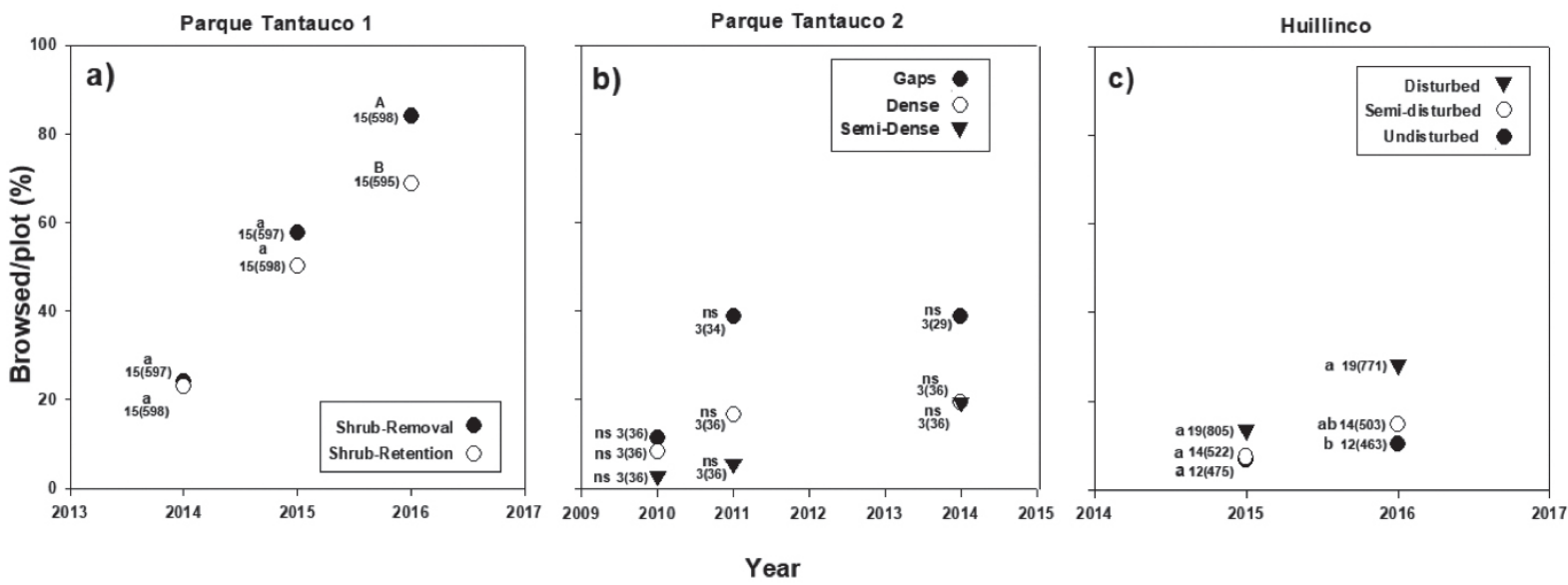

Figure 3: Browsing rates over years with indicated number of plots and living plants in brackets. a) Parque Tantauco 1, Pilgerodendron uviferum seedlings in clusters with "shrub-retention" and "shrub-removal", b) Parque Tantauco 2, Pilgerodendron uviferum seedlings under different light conditions, and c) Huillinco, Nothofagus nitida along a gradient of different light conditions. Capital letters for $\mathrm{p}<0.01$, small letters for $\mathrm{p}<0.05$, ns $=$ non-significant. $/$ Tasas de ramoneo con el número indicado de parcelas y plantas vivas entre paréntesis. a) Parque Tantauco 1, plántulas de Pilgerodendron uviferum en núcleos con "retención de matorral" y "remoción de matorral", b) Parque Tantauco 2, plántulas de Pilgerodendron uviferum bajo diferentes condiciones de luz, y c) Huillinco, Nothofagus nitida a lo largo de un gradiente de diferentes condiciones lumínicas. Mayúsculas para $\mathrm{p}<0,01$, letras minúsculas para $\mathrm{p}<0,05$, ns $=$ no significativo.
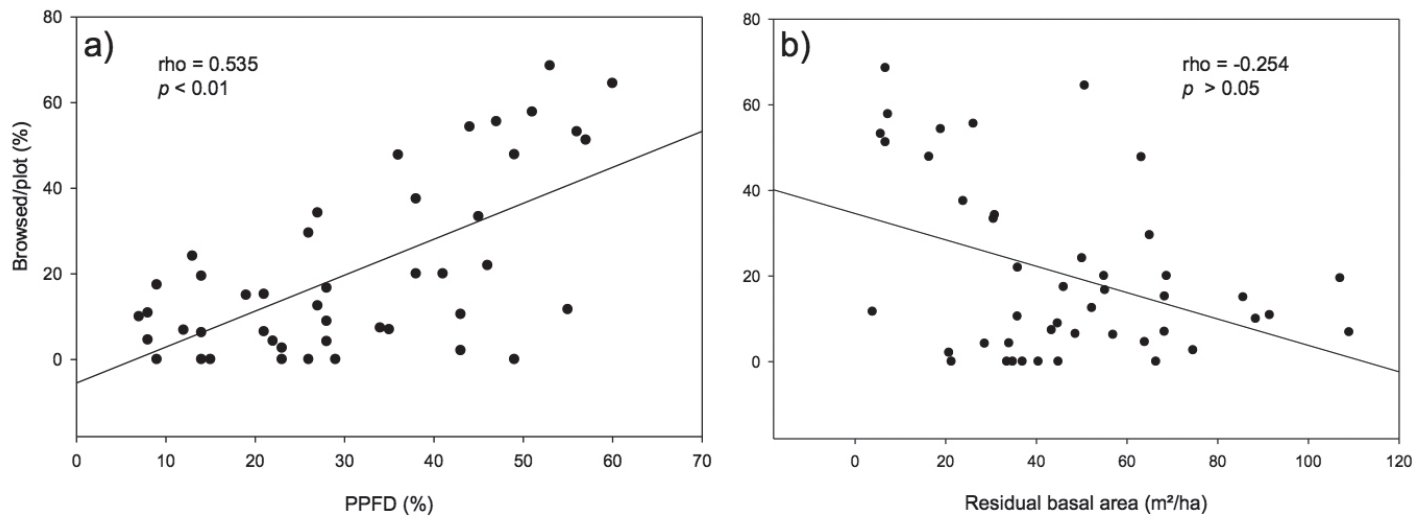

FIgURE 4: Relation between browsing rate and a) Photosynthetically Photon Flux Density (\%PPFD) and b) residual basal area $\left(\mathrm{m}^{2} \mathrm{ha}^{-1}\right)$ in Huillinco experiment. / Relación entre la tasa de ramoneo y a) Photosynthetically Photon Flux Density (\% PPFD) y b) área basal residual $\left(\mathrm{m}^{2} \mathrm{ha}^{-1}\right)$ en el experimento de Huillinco. 


\section{DISCUSSION}

Browsing EVIDENCE IN RESTORATION Plantings ON ChiloÉ ISLAND

While we determined the existence of browsing by pudu in all the analyzed restoration experiments on Chiloé Island, the browsing rate varied at different levels of light and disturbance in terms of the treatments applied in each experiment. In Parque Tantauco 1, an open landscape without tree overstory but with a dense shrub cover (understory), we found significantly higher browsing rates for Pilgerodendron uviferum seedlings in clusters with shrub removal. Furthermore, in upland conditions (Parque Tantauco 2) we determined higher browsing of Pilgerodendron uviferum seedlings along a gradient of decreasing tree overstory. While there was no significant difference, it was possible to note a tendency of higher browsing rates in "gaps" than "semi-dense" and "dense" conditions. These finding support our first hypothesis that in burned forests, $P$. uviferum planted seedlings present higher browsing rates in places with lower shrub cover (bogs) and canopy cover (upland areas). Similarly, in Huillinco browsing rates for Nothofagus nitida seedlings significantly increased along a gradient of tree overstory degradation. We were able to find a link between the openness of the tree overstory in our restoration plantings, which was defined by means of \%PPFD and residual basal area measurements, and higher browsing rates. Although \%PPFD showed significant correlation with residual basal area (cor: $-0.70 ; p<0.01$ ), browsing rates did not significantly correlate with residual basal area. However, we observed a clear preference of pudus to those disturbed sites with lower residual basal area (e.g. disturbed forest). This pattern confirms our second hypothesis that in degraded North-Patagonian forests, $N$. nitida planted seedlings present higher browsing rates in places with higher \%PPFD and/or lower residual basal area. For both removal of the understory and reduced (degraded) tree overstory, higher browsing rates have been found for many species and forest types worldwide (Horsley et al. 2003, Tremblay et al. 2007, Kuijper et al. 2009, Churski et al. 2016, Forbes et al. 2016, Charron \& Hermanutz 2017, Bose et al. 2018). However, this pattern has shown controversial results for different species worldwide and thus, is a widely discussed issue (Casabon \& Pothier 2007, Tremblay et al. 2007, Kuijper et al. 2009, Gerhardt et al. 2013). For example, some studies have shown lower browsing impacts in sites with absent or reduced tree overstory as a result of reduced hiding chances and concomitant higher predation risks (Casabon \& Pothier 2007). In contrast, both pudus' low predation risk in Chiloé Island and the hunting ban, can explain its loss of fear to open sites, especially in isolated areas without human and domestic dog pressures.

While pudus feed on many different species, a preference to some species has been observed (Eldridge et al. 1987, Jiménez 2010). Species-specific browsing has also been recognized for other deer species in Europe (e.g. Cervus elaphus Linnaeus, 1758) and North America (e.g. Odocoileus virginianus Zimmermann, 1780) and is usually due to higher nutrient contents in some species' leaves (Gill 1992, Casabon \& Pothier 2007, Gerhardt et al. 2013). Consequently, this pattern indicates particular relevance for species composition and forest dynamics (Faison et al. 2016), which play an important role in restoration programs, when mixed forests are to be developed. Especially slow-growing species, like Pilgerodendron uviferum, could be affected, rendering it almost impossible to escape the browsing line. Yet, with a deeper knowledge on nutritional compounds of leaves, attractive species could be identified "non-destructively". In accordance to Jiménez (2010), Nothofagus nitida is among the commonly browsed tree species. Due to the limited number of restoration experiments as well as tree species, we cannot clearly confirm species-specific browsing for one or the other tree species in this study. However, in other plantings not included in this study, we found that seedlings of the species Gevuina avellana Molina are almost not browsed in comparison with other native species like Embothrium coccineum J.R. Forst. \& G. Forst. or Eucryphia cordifolia Cav. Even though absolute results are not yet published, this effect should be highlighted in future research as it contains potential for new approaches in forest restoration. Therefore, we expect more details on species-specific browsing and palatability as valuable information in forest restoration (Gerhardt et al. 2013, Burney \& Jacobs 2018).

Nonetheless, restoration experiments presumably constitute different situations, where planted seedlings in gaps offer a more accessible (Graham et al. 1992) and plentiful feeding site particularly in comparison to natural forests. Accordingly, our restoration experiments might present a more unnatural and nutritious habitat (Gerhardt et al. 2013) for pudus. Therefore, the question arises for all restoration plantings in our study, if the adjacent and artificially disturbed restoration sites constituted overcompensatory browsing sites for pudu, which simply rendered denser sites too difficult to reach and hence, were avoided due to lower attractiveness. That assumption is addressing the experimental design though, while there is no doubt on the general effects of open sites that has been similarly approved in other studies (Horsley et al. 2003, Tremblay et al. 2007, Churski et al. 2016). Besides, our restoration plantings have different historical backgrounds as well as periods since establishment. However, both burned forests (Parque Tantauco 1 and 2) and degraded secondary forests (Huillinco) present similar high browsing rates. Hence, we cannot determine differences in the types of previous disturbance but in the degree of (non-) degradation. Similarly, the time periods of 2 (Huillinco), 3 
(Parque Tantauco 1), or 5 years (Parque Tantauco 2) do not show a temporal pattern of higher browsing over time. As a consequence, higher browsing in our restoration plantings is rather reasoned by different site preparations/treatments or preconditions.

IMPLICATIONS FOR FOREST RESTORATION

As pudus justifiably constitute protected animals, particular attention of forest restoration is required. The reason for the need of a partly different forest management in Chiloé Island compared to many European or North American forests, is that hunting and reintroducing top-predators is very often regarded as the solution there (Kuijper 2011). While that is not an option in Chiloé, similar negative impacts on restoration plantings can be expected, which hinder forest redevelopment by reduced growth and survival in general (Partl et al. 2002, Faison et al. 2016). For that reason, we suggest orientating restoration management to different considerations in order to reduce browsing, like for example browsing protection, seedling size and site preparation.

As browsing protection for seedlings, chain-link fences should be installed around cluster plantings. Individually implemented physical barriers, such as mesh guards or tubes for the whole plant, are also an option (Graham et al. 2010). Due to pudu's short height, browse protection of $1 \mathrm{~m}$ is sufficient. Accordingly, protection in terms of fences, guards or tubes are less important for planted seedlings exceeding $1 \mathrm{~m}$ in height in order to avoid browsed apical shoots and escape the browsing line. Special protection is essential to avoid browsing when seedlings of short height $(<1 \mathrm{~m})$ are planted in places were the understory was removed (Gerhardt et al. 2013). In contrast, seedlings of $>1 \mathrm{~m}$ are less affected by dense understory in terms of growth competition as well as browsing, since pudus do not reach $>1 \mathrm{~m}$ plus dense understory further reduces browsing accessibility; hence, browsing protection is less important. In spite of the advantage of planting taller seedlings, higher costs, time-consume, and vulnerability to root damage need to be considered. Alternatively, chemical repellents can be directly placed on the seedlings apical shoot or around the restoration sites; however, they only constitute a short-lived solution owing to fast degradation and dilution in highprecipitation areas like Chiloé Island.

Based on our results, forest restoration efforts in Chiloé Island and other places that share similar landscape characteristics will face a great challenge in the next years that is balancing the protection of Near Threatened wildlife with the restoration of native tree species, many of them with conservation problems. In this context, there is a need of rethinking the designs of restoration plantings in open/disturbed areas, where higher browsing was found. In accordance with our expectations, browsing by pudus indicated to be a widespread problem in restoration plantings on Chiloé Island. This evidence will increase the complexity and costs of forest restoration in degraded forests on Chiloé Island, where pudus may have its ideal habitat for persistence.

\section{ACKNOWLEDGEMENTS}

We thank the administration and staff of the Tantauco Park for constant help and support in the field. We also thank many field assistants that helped us under difficult conditions in the field. AB thanks the opportunity to get to know one of the most wonderful regions on earth: North Patagonia. RVG thanks to CONICYT-PAI 821320069 and Vicerrectoría de Investigación y Postgrado Universidad de la Frontera. This is a contribution to the forest restoration research program of Instituto Forestal. This work was supported by FONDECYT Initiation into Research N¹1160191, FIBNCONAF 2015/020 and MINAGRI.

\section{REFERENCES}

BANNISTER, J.R. 2012. Dynamics and restoration of Pilgerodendron uviferum forests on Chiloé Island, North Patagonia, Chile. Thesis. Faculty of Environment and Natural Resources, University of Freiburg. Freiburg, Germany. 85 pp.

Bannister, J.R., Coopman, R., Donoso, P., Bauhus, J. 2013. The importance of microtopography and nurse canopy for successful restoration planting of the slow-growing conifer Pilgerodendron uviferum. Forests 4(1): 85-103.

BAnNister, J.R., Donoso, P.J. 2013. Forest typification to characterize the structure and composition of old-growth evergreen forests on Chiloe island, North Patagonia (Chile). Forests 4: 1087-1105.

Bannister, J.R., Donoso, P.J., MujicA, R. 2016. La Silvicultura como herramienta para la restauración de bosques templados. Bosque 37:229-235.

Bannister, J.R., Vidal, O.J., Teneb, E., Sandoval, V. 2012. Latitudinal patterns and regionalization of plant diversity along a 4270-km gradient in continental Chile. Austral Ecology 37: 500-509.

Bannister, J.R., Wagner, S., Donoso, P., Bauhus, J. 2014. The importance of seed trees in the dioecious conifer Pilgerodendron uviferum for passive restoration of fire disturbed southern bog forests. Austral Ecology 39: 204213.

Bose, A.K., Wagner, R.G., Roth, B.E., Weiskittel, A.R. 2018. Influence of browsing damage and overstory cover on regeneration of American beech and sugar maple nine years following understory herbicide release in central Maine. New Forests 49(1): 67-85.

Bubenik, G.A., Reyes, E., Schams, D., Lobos, A., Bartoš, L. 2000. Pudu, the smallest deer of the world: 10 years of endocrine studies of Southern Pudu (Pudu puda) in Chile. Zeitschrift für Jagdwissenschaft 46(3): 129-138.

Burney, O.T., JACOBS, D.F. 2018. Species selection - A fundamental silvicultural tool to promote forest regeneration under high animal browsing pressure. Forest Ecology and 
Management 408: 67-74.

Casabon, C., Pothier, D. 2007. Browsing of tree regeneration by white-tailed deer in large clearcuts on Anticosti Island, Quebec. Forest Ecology and Management 253(1-3): 112119.

Cavieres, L.A., Fajardo, A. 2005. Browsing by guanaco (Lama guanicoe) on Nothofagus pumilio forest gaps in Tierra del Fuego, Chile. Forest Ecology and Management 204(2-3): 237-248.

Chapman, J.L., Reiss, M.J. 1999. Ecology: Principles and applications. Cambridge University Press, Cambridge, U.K. 330 pp.

Charron, L., Hermanutz, L. 2017. Simplicity is key: Restoration protocols for nonregenerating forests degraded by overabundant herbivores. Restoration Ecology 25(3): 432441.

Churski, M., Bubnicki, J.W., Jedrzejewska, B., Kuijper, D.P.J., Cromsigt, J.P.G.M. 2016. Brown world forests: increased ungulate browsing keeps temperate trees in recruitment bottlenecks in resource hotspots. New Phytologist 214(1): 158-168.

Clasen, C., Heurich, M., Glaesener, L., Kennel, E., Knoke, T. 2015. What factors affect the survival of tree saplings under browsing, and how can a loss of admixed tree species be forecast? Ecological Modelling 305: 1-9.

Collado, L., Farina, S., Jaras, F., Vargas, H. 2008. Monitoring of harvesting and regeneration state of a Nothofagus pumilio forestry management plan located near the forest-steppe bord. Bosque 29(1): 85-90.

Côté, S.D., Rooney, T.P., Tremblay, J.-P., Dussault, C., Waller, D.M. 2004. Ecological Impacts of Deer Overabundance. Annual Review of Ecology, Evolution, and Systematics 35(1): 113-147.

Di Castri, F., Hajek, E. 1976. Bioclimatología de Chile. Vicerrectoría Académica de la Universidad Católica de Chile, Santiago, Chile. 128 pp.

Echevarría, D.C., Müller, A.R. Von, Hansen, N.E., Bava, J.O. 2014. Efecto del ramoneo bovino en renovales de Nothofagus antarctica en Chubut, Argentina, en relación con la carga ganadera y la altura de las plantas. Bosque (Valdivia) 35(3): 353-368.

Eldridge, W.D., Macnamara, M.M., Pacheco, N.V. 1987. Activity patterns and habitat utilization of pudus (Pudu puda) in South-Central Chile. In: Wemmer, C.M. (ed.). Biology and management of the Cervidae, pp 352-370. Smithsonian Institution Press: Washington, USA.

Faison, E.K., Destefano, S., Foster, D.R., Rapp, J.M., Compton, J.A. 2016. Multiple Browsers Structure Tree Recruitment in Logged Temperate Forests. PloS ONE 11(11): e0166783.

Forbes, A.S., Norton, D.A., Carswell, F.E. 2016. Artificial canopy gaps accelerate restoration within an exotic Pinus radiata plantation. Restoration Ecology 24(3): 336-345.

Fox, J., Weisberg, S. 2011. An R companion to applied regression. Second edition. Sage, Thousand Oaks, CA. URL: http:// socserv.socsci.mcmaster.ca/jfox/Books/Companion.

Gerhardt, P., Arnold, J.M., Hackländer, K., Hochbichler, E. 2013. Determinants of deer impact in European forests - A systematic literature analysis. Forest Ecology and Management 310: 173-186.

GILL, R.M.A. 1992. A review of damage by mammals in north temperate forests: 1. Deer. Forestry 65(2): 145-169.

Glade, A. 1985. El pudú, un silencioso habitante de nuestros bosques: Corporación Nacional Forestal, Chile. Technical Bulletin Series Fauna 11: 1-6.

Graham, R.T., Jain, T.B., Kingery, J.L. 2010. Ameliorating conflicts among deer, elk, cattle and/or other ungulates and other forest uses: A synthesis. Forestry 83(3): 245-255.

Graham, R.T., Kingery, J.L., Volland, L.A. 1992. Livestock and forest management interactions. In: Black, H.C. (ed.), Silvicultural approaches to animal damage management in Pacific Northwest Forests. Chap 17: 351-364. Pacific Northwest Research Station, Oregon, USA.

Grosse, H.W. 2001. La regeneración de Lenga en Magallanes: In the report of the Instituto Forestal (INFOR) for the FONDEMA (Fondo de Desarrollo de Magallanes) project on natural regeneration of Lenga (Nothofagus pumilio).

Horsley, S.B., Stout, S.L., Decalesta, D.S. 2003. White-tailed deer impact on the vegetation dynamics of a northern hardwood forest. Ecological Applications 13(1): 98-118.

JimÉnEZ, J.E. 1995. Responses of pudus (Pudu puda) to human disturbances in Neotropical temperate rainforests. Final Report for the Lincoln Park Zoo Scott Neotropic Fund 1: 113.

JimÉnez, J.E. 2010. Southern pudu Pudu puda (Molina 1782). In: Duarte, J.M.B., González, S. (eds.), Neotropical Cervidology: Biology and medicine of Latin American deer, Chap.: 14, pp. 140-150. Funep/IUCN, Jaboticabal, Brazil.

Jiménez, J.E., Marquet, P.A., Medel, R. 1990. Comparative ecology of Darwin's fox (Pseudalopex fulvipes) in mainland and island settings of southern Chile. Revista Chilena de Historia Natural 63: 177-186.

KUIJPER, D.P.J. 2011. Lack of natural control mechanisms increases wildlife-forestry conflict in managed temperate European forest systems. European Journal of Forest Research 130(6): 895-909.

Kuijper, D.P.J., Cromsigt, J.P.G.M., Churski, M., Adam, B., JęDrzejewska, B., JęDrzeJewski, W. 2009. Do ungulates preferentially feed in forest gaps in European temperate forest? Forest Ecology and Management 258(7): 15281535.

Lusk, C.H., Ortega, A. 2003. Vertical structure and basal area development in second-growth Nothofagus stands in Chile. Journal of Applied Ecology 40(4): 639-645.

Martínez Pastur, G., Peri, P., Fernández, C., Staffieri, G., Rodríguez, D.S. 1999. Desarrollo de la regeneración a lo largo del ciclo del manejo forestal de un bosque de Nothofagus pumilio 2. Incidencia del ramoneo de Lama guanicoe. Bosque 20(2): 47-53.

MоттA, R. 1996. Impact of wild ungulates on forest regeneration and tree composition of mountain forests in the Western Italian Alps. Forest Ecology and Management 88(1-2): 9398.

Myers, N., Mittermeier, R.A., Mittermeier, C.G., Da Fonseca, G.A., KENT, J. 2000. Biodiversity hotspots for conservation priorities. Nature 403(6772): 853-858.

Neumann, A. 1992. El pudú (Pudu pudu, Molina), contribución a su estudio etológico. Osorno: Ediciones Impresur.

Partl, E., Szinovatz, V., Reimoser, F., Schweiger-Adler, J. 2002. Forest restoration and browsing impact by roe deer. Forest 
Pudu browsing in restoration plantings of Chiloé Island: Burger, A. ET AL.

Ecology and Management 159(1-2): 87-100.

Pohlert, T. 2014. The pairwise multiple comparison of mean ranks, package (PMCMR). R Package, http://CRAN.Rproject.org/package $=$ PMCMR.

Promis, A., Gärtner, S., ReIF, A., Cruz, G. 2010. Effects of natural small-scale disturbances on below-canopy solar radiation and regeneration patterns in an old-growth Nothofagus betuloides forest in Tierra del Fuego, Chile. Allgemeine Forst- und Jagdzeitung 181 (3/4):53-64.

Puig, S., Rosi, M.I., Videla, F., Mendez, E. 2014. Food selection by the guanaco (Lama guanicoe) along an altitudinal gradient in the Southern Andean Precordillera (Argentina). Acta Theriologica 59(4): 541-551.

R CoRE TEAm. 2016. R: A Language and Environment for Statistical Computing. Vienna, Austria: The R Foundation for Statistical Computing. ISBN: 3-900051-07-0. Available online at http://www.R-project.org/. $\mathrm{R}$ version 3.3.1 (2016-06-21).

Rebertus, A.J., Kitzberger, T., Veblen, T.T., Roovers, L.M. 1997. Blowdown History and Landscape Patterns in the Andes of Tierra del Fuego, Argentina. Ecology 78(3): 678.

SIGMAPLOT. 2016. Systat Software, San Jose, CA: Version 10.0.0.54.
Silva-Rodríguez, E.A., Pastore, H., Jiménez, J. 2016. Pudu puda: The IUCN Red List of Threatened Species 2016: e.T18848A22164089. Downloaded on 19 January 2017.

Silva-Rodríguez, E.A., Sieving, K.E. 2012. Domestic dogs shape the landscape-scale distribution of a threatened forest ungulate. Biological Conservation 150(1): 103-110.

Sweetapple, P.J., Nugent, G., Whitford, J., Latham, M.C., Pekelharing, K. 2016. Long-term response of temperate canopy trees to removal of browsing from an invasive arboreal herbivore in New Zealand. Austral Ecology 41(5): 538-548.

Tremblay, J.-P., Huot, J., Potvin, F. 2007. Density-related effects of deer browsing on the regeneration dynamics of boreal forests. Journal of Applied Ecology 44(3): 552-562.

VILLÁGRAN, C. 1988. Late Quaternary vegetation of southern Isla Grande de Chiloé, Chile. Quaternary Research 29(3): 294-306.

Wetterberg, G.B. 1972. Pudu in a Chilean National Park. Oryx 11: 347-351.

White, M.A. 2012. Long-term effects of deer browsing: Composition, structure and productivity in a northeastern Minnesota old-growth forest. Forest Ecology and Management 269: 222-228.

Recibido: 23.07.2018

Aceptado: 12.12.2018 